\title{
Metaphors and Marriage Plots: Jane Eyre, The Egoist, and Metaphoric Dialogue in the Victorian Novel
}

\author{
Erik Gray \\ Columbia University
}

One of the most distinctive features of Victorian dialogue is the speakers' tendency to pick up and develop one another's metaphors. This practice appears as frequently in actual recorded conversations as it does in fictional ones. Consider, for instance, the interchange that Alfred Tennyson is reported to have had with the aged Thomas Carlyle. The two men were debating the possibility of life after death, which Carlyle categorically denied, by way of a metaphor. "Why should we expect a hereafter?" he demanded of Tennyson. "Your traveller comes to an inn, and he takes his bed, it's only for one night, he leaves next day, and another man takes his place and sleeps in the bed that he has vacated." To this Tennyson responded in kind: "Your traveller comes to his inn, and lies down in his bed, and leaves the inn in the morning, and goes on his way rejoicing, with the sure and certain hope and belief that he is going somewhere, where he will sleep the next night" (Tennyson II: 410).

There is nothing unusual in one speaker's adopting the tone of his interlocutor, or even specific words; to the contrary, that has always been, and still remains, a sign of conversational skill. What is so striking, however, and so characteristic about Tennyson's reply is that he is disagreeing with Carlyle. Yet rather than challenging the validity of Carlyle's metaphor, which would probably be the more natural reaction today (and which is also the tactic recommended by the Roman orator Quintilian), ${ }^{1}$ Tennyson instead affirms Carlyle's metaphor, and then pursues it to a different end. Tennyson thus manages to suggest a fundamentally shared sensibility with his old friend, even as he asserts a contradictory opinion.

Tennyson was, by all accounts, a much more attentive husband than Carlyle. ${ }^{2}$ This might seem an irrelevant observation, unconnected to Ten-

\footnotetext{
1 "Quintilian advised that the best way to refute a simile in debate is to "lay stress on [the] extreme dissimilarity' (dissimilia) of what is being compared" (Wolfson 72, citing Quintilian, Institutio oratoria 5.13.24).

${ }^{2}$ For a sensitive, balanced account of the Carlyles' marriage - its "stability and affection" as well as its more notorious "frustration and annoyance" (258) - see Rose, chs. 1 and 6.
} 
nyson's use of this conversational trope; but in fact metaphor and marriage are intimately aligned. The Book of Common Prayer, for example, explicitly asserts that marriage itself is a metaphor. At the beginning of every Anglican wedding, the minister is instructed to remind the congregants that God instituted matrimony as "an honourable estate, ... signifying unto us the mystical union that is betwixt Christ and his Church" (Book 219). The metaphorical nature of marriage is then reinforced by a quotation from St. Paul: "For the husband is the head of the wife just as Christ is the head of the Church" (224). By the same token, literary theorists frequently describe metaphor in terms suggestive of erotic or conjugal union, as the splicing together of diverse but complementary concepts. As Julia Kristeva writes, "philosophical thought on metaphor is rooted, with Plato, in a reflection on love" (275). In Plato's Phaedrus, the discovery of one's true mate depends upon the perception of resemblances - "which has the advantage, at the very dawn of Greek thought, of placing love in concert with ... homologation" (269).

Nineteenth-century writers, particularly the Romantics, drew similar connections between metaphor and love or marriage. ${ }^{3}$ As Adrian Daub observes, "Jean Paul [Richter] characterizes his role vis-à-vis his metaphors ... as that of a priest marrying off separate objects" (257). Similarly, Susan Wolfson cites an early poem by Samuel Taylor Coleridge ("A Simile") that describes a married couple in terms traditionally reserved for describing a metaphor, and another by John Keats ("Alexandre the Conqueroure") in which "[i]n a characteristic Keatsian conflation, erotic and poetic success are ... both measured by a capacity to generate similes" (83). But the most important Romantic formulation of the erotics of metaphor comes from William Wordsworth. Aristotle had influentially defined the talent for metaphor as "an intuitive perception of the similarity in dissimilars" (1459a; ch. 22: 71). ${ }^{4}$ Taking up Aristotle's language, Wordsworth directly connects this rhetorical capacity to personal and specifically erotic relationships. In a famous passage from the Preface to Lyrical Ballads (1800), Wordsworth describes "the pleasure which the mind derives from the perception of similitude in dissimilitude.... From

\footnotetext{
${ }^{3}$ The most Platonic of the English Romantics in this respect is Percy Shelley; on Shelley's linking of love and metaphor see Gray 301-304.

${ }^{4}$ Not all translations of the Poetics include the phrase "in dissimilars." But as Ingram Bywater points out in his note to this passage (302), Aristotle specifies the need for likenessin-difference in his very similar discussion of metaphor in the Rhetoric (1412a): since metaphor involves only similarity, not sameness, it requires a perception of "the similarity even in things very distinct" (to homoion kai en polu diekhousi).
} 
this principle the direction of the sexual appetite, and all the passions connected with it take their origin" (I: 148).

Wordsworth's emphasis on "dissimilitude" is significant, since a certain amount of dissimilarity or disagreement is crucial alike to metaphor and to marriage. As David Punter explains, "although metaphor undoubtedly deals in likeness, similarity, it also deals in unlikeness and dissimilarity. Metaphor makes us look at the world afresh, but it often does so by challenging our notions of the similarity that exists between things," revealing "in what ways, in fact, they are irreconcilably unalike" (9). And marriage, of course, depends even more upon dissimilarity. Like metaphor, marriage requires you to find someone compatible yet fundamentally different. You are not allowed, by definition, to marry a member of your immediate family; nor, in the Anglican church, are you allowed to marry someone of the same sex as yourself. In fiction the demand for dissimilarity between marriage partners goes even further. A marriage plot in which the hero and heroine are too perfectly suited would be as unsatisfying as a simile that corresponded at every point - a tautology. (As Coleridge notes, "No simile runs on all four legs" [86].5) Hence, as Joseph Allen Boone points out, the novelistic tradition, in keeping with an earlier folkloric tradition, requires some form of basic opposition between its lovers. The "paradigm [that] generally characterizes the successful courtship plot" pictures "the harmonious union of ... complementary opposites" (Boone 11). In the marriage plot, as in metaphor, successful union begins with difference - dissimilitude in similitude.

This applies just as much to actual marriage plots as to fictional ones. In his first letter to Elizabeth Barrett, Robert Browning makes use of an elaborate metaphor. Recalling a time when he nearly met Barrett but was prevented at the last moment by her illness, he describes his reaction thus:

[Y]ou were too unwell - and now it is years ago - and I feel as at some untoward passage in my travels - as if I had been close, so close, to some world's-wonder in chapel or crypt, only a screen to push and I might have entered, but there was some slight . . so it now seems . . slight and

${ }^{5}$ In Table Talk Coleridge wrote, in the same vein, "The Difference is as essential to it as the Likeness, for without the Difference, it would be Copy or Fac-simile," and in a lecture of 1818 he remarked, "No simile is expected to be compleat in all points - Else it would not be a Simile, but an Instance" (Wolfson 71, 93). Coleridge is referring in these cases specifically to similes; throughout this essay, I treat simile as a subset of metaphor, using "metaphor," as Aristotle does in chapter 21 of Poetics, in its broadest sense, to indicate a figure in which the name of one thing is transferred to another that resembles it. 
just-sufficient bar to admission; and the half-opened door shut, and I went home my thousands of miles, and the sight was never to be! (Kintner 3-4; suspension marks thus in the original)

In her reply Barrett gently ridicules Browning's fantasy:

[C]an it be true that you look back upon the lost opportunity with any regret? BuT . . you know . . if you had entered the "crypt," you might have caught cold, or been tired to death, \& wished yourself "a thousand miles off" - which would have been worse than travelling them. (ibid., 5)

Yet Barrett's reply remains encouraging: even as she corrects Browning's over-exuberance, she nevertheless enters into his metaphor.

When characters in Victorian novels similarly take up, and often challenge or repurpose, one another's metaphors, it serves as an important marker of marital compatibility. ${ }^{6}$ The trope is by no means peculiar to this period - it appears not only in earlier novels but also in Shakespeare, notably in the stichomythic banter of the comedies - but in this essay I suggest why it gains particular significance, and perhaps a particular currency, in Victorian fiction. I begin with Charlotte Brontë's Jane Eyre (1847), which offers a relatively straightforward example of a marriage plot marked by the sharing of metaphors, and then turn to the more complex case of George Meredith's The Egoist (1879). Based on these readings, I propose two major reasons why it is important to be attuned to this narratological trope. In the first place, the trope reflects upon the nature of matrimony. It serves as a reminder that marriage, as the Victorians recognized, is inherently a discursive phenomenon, as much as a physical and spiritual one; just as importantly, it draws attention to a significant shift in the conception of matrimony in England over the course of the Victorian period, from an ideal of marriage as total merging towards an increasing recognition of distinction within union. Second, given the close relation of marriage and metaphor, the practice of sharing metaphor can serve in a novel, not just as a marker, but as a microcosm of conjugal compatibility. Even in novels that end as soon as the lovers get married, these dialogues permit us to witness, in essence, a marital relationship.

\footnotetext{
${ }^{6}$ Sharing of metaphors does not occur only between nubile characters, of course; as noted above, it features regularly in all sorts of Victorian conversations. But it takes on a special meaning when the participants are potential partners. For a good discussion of flirtatious behavior in nineteenth-century fiction see Richard Kaye, The Flirt's Tragedy, although Kaye concentrates on non-teleological interactions, rather than on courtship.
} 
It would be possible to offer a schematic account of the relationship between Jane Eyre and Mr. Rochester entirely through the metaphors that they share. Already in the first conversation in which they engage after their accidental encounter in Hay Lane, Jane displays a knack for picking up Rochester's tone and imagery - to the bewilderment of the elderly Mrs. Fairfax, who is sitting nearby.

"And so you were waiting for your people when you sat on that stile?"

"For whom, sir?"

"For the men in green: it was a proper moonlight evening for them. Did I break through one of your rings, that you spread that damned ice on the causeway?"

I shook my head. "The men in green all forsook England a hundred years ago," said I, speaking as seriously as he had done. "And not even in Hay Lane or the fields about it could you find a trace of them. I don't think either summer or harvest, or winter moon, will ever shine on their revels more."

Mrs. Fairfax had dropped her knitting, and with raised eyebrows, seemed wondering what sort of talk this was. (139)

It is notable that although Jane adopts Rochester's image of elves, she does so only to contradict him. This habit continues in their next extended conversation, when the talk becomes more distinctly metaphorical.

"Besides, since happiness is irrevocably denied me, I have a right to get pleasure out of life: and I will get it, cost what it may."

"Then you will degenerate still more, sir."

"Possibly: yet why should I, if I can get sweet, fresh pleasure? And I may get it as sweet and fresh as the wild honey the bee gathers on the moor."

"It will sting - it will taste bitter, sir." (155)

Jane's response to Rochester's bee metaphor is rather confused: her first "it" apparently refers to the bee, the second to the honey. But the coherence of the metaphors is less significant than Jane's willingness to enter into a shared metaphorical discourse with Rochester - even for the purpose, once more, of correcting or reprimanding him.

Such willingness distinguishes Jane from Blanche Ingram, the society beauty whom everyone, including Jane, believes that Rochester will marry. During her visit to Thornfield Blanche speaks to Rochester flirtatiously, and he responds in a similar tone. Yet when he then proposes a metaphor, comparing Blanche to Mary Queen of Scots and himself to the 
queen's lover, David Rizzio, Blanche quickly and rather vulgarly rejects his metaphor - and, by extension, him:

"Signior Eduardo, are you in voice to-night?"

"Donna Bianca, if you command it, I will be."

"Then Signior, I lay on you my sovereign behest to furbish up your lungs and other vocal organs, as they will be wanted on my royal service."

"Who would not be the Rizzio of so divine a Mary?"

"A fig for Rizzio!" cried she, tossing her head with all its curls. (202)

The metaphor Rochester chooses here is portentous, since Rizzio never married Queen Mary and never could have, as she was already married. But once again, even more significant than the metaphor itself is Blanche's refusal to enter into it.

The climactic scene of the first half of the novel, when Rochester proposes to Jane, makes complex use of the trope. At first Jane still believes Rochester to be engaged; when he kisses her, therefore, she rejects both his embrace and, for once, his metaphor:

"Jane, be still; don't struggle so, like a wild, frantic bird that is rending its own plumage in its desperation."

"I am no bird; and no net ensnares me: I am a free human being with an independent will." (284)

Yet Rochester persists and finally proposes to Jane, not through a metaphor, exactly, but by insisting that they themselves are an embodied metaphor - a matched likeness:

"Come, Jane - come hither."

"Your bride stands between us."

He rose, and with a stride reached me.

"My bride is here," he said, again drawing me to him, "because my equal is here, and my likeness. Jane, will you marry me?" (285, italics added)

Jane remains incredulous, until Rochester, picking up on a slight hint in Jane's speech, develops the textual metaphor she has introduced:

"Mr Rochester, let me look at your face: turn to the moonlight." "Why?"

"Because I want to read your countenance; turn!"

"There: you will find it scarcely more legible than a crumpled, scratched page. Read on: only make haste, for I suffer." (286) 
This interchange, significantly, marks the first time in the novel that Rochester takes up and pursues a metaphor that Jane has proposed, rather than the other way around. Ten lines later, they are engaged.

But the story of course does not end there. Strikingly, the first metaphor Rochester proposes to Jane the morning after their engagement fails to take.

"Ten years since, I flew through Europe half mad; with disgust, hate, and rage, as my companions: now I shall revisit it healed and cleansed, with a very angel as my comforter."

I laughed at him as he said this. "I am not an angel," I asserted; "and I will not be one till I die: I will be myself." (292)

Jane may be laughing, but it nevertheless seems ominous that she rejects the angel metaphor as decisively as she had earlier rejected the bird metaphor. Rochester's hopes are soon dashed: his wedding to Jane is broken off before they can pronounce their vows. And yet, even after this disaster, the text still offers cause for hope, in the form of perhaps the most subtle and most touching shared metaphor in the novel. At the beginning of the proposal scene, Rochester had introduced a memorable image to describe his feeling of attachment to Jane.

"I sometimes have a queer feeling with regard to you - especially when you are near me, as now: it is as if I had a string somewhere under my left ribs, tightly and inextricably knotted to a similar string situated in the corresponding quarter of your little frame. And if that boisterous channel, and two hundred miles or so of land come broad between us, I am afraid that cord of communion will be snapt; and then I've a nervous notion I should take to bleeding inwardly." (283)

At the time Jane had been too overcome with emotion to respond. Yet a month later, immediately after her failed wedding, and even as she resolves to leave Rochester forever, Jane takes up his earlier metaphor:

"If I could go out of life now, without too sharp a pang, it would be well for me," I thought; "then I should not have to make the effort of cracking my heart-strings in rending them from among Mr Rochester's. I must leave him, it appears." (357)

The passage is cast as direct discourse, but silent: the metaphor is articulated, but it cannot be spoken. Nevertheless, Jane's willingness to adopt Rochester's metaphor holds out a promise of reconciliation.

The reconciliation finally comes many months later, at the end of the novel, in the garden at Ferndean, when Rochester compares himself to a tree, and Jane, according to her old habit, embraces his metaphor: 
"I am no better than the old lightning-struck chestnut-tree in Thornfield orchard," he remarked ere long. "And what right would that ruin have to bid a budding woodbine cover its decay with freshness?"

"You are no ruin, sir - no lightning-struck tree: you are green and vigorous. Plants will grow about your roots, whether you ask them or not, because they take delight in your bountiful shadow; and as they grow they will lean towards you, and wind round you, because your strength offers them so safe a prop." (493)

As usual, Jane affirms the essential points of the metaphor - Rochester as a tree, herself as a flowering plant - while also offering a necessary corrective; and both the dialogue and their relationship are stronger for the element of disagreement she introduces. Ten lines later, they are engaged again, this time for good.

\section{$\star \star \star$}

If the only value of this trope lay in helping the reader to guess which characters will marry one another, it would be of little interest: predicting the outcome of a marriage plot is not an especially difficult or fruitful exercise. But the dialogic sharing of metaphor, which appears pervasively in novels of the Victorian period, ${ }^{7}$ carries real significance beyond its utility as a predictive sign. In what follows I draw my illustrations from The Egoist, which is particularly rich in both metaphors and marriage plots. Meredith's novel bristles with figurative language, shared gener-

${ }^{7}$ Once one begins to notice the trope, one finds it everywhere in Victorian fiction. Here, for instance, is an interchange from Anthony Trollope's Framley Parsonage (1861), part of a scene between Lord Lufton and Lucy Robarts that culminates in an unplanned proposal:

"That is why I have liked you so much," he continued, "because you get out of the grooves."

"Do I?"

"Yes; and go along by yourself, guiding your own footsteps; not carried hither and thither, just as your grandmother's old tramway may chance to take you."

"Do you know I have a strong idea that my grandmother's old tramway will be the safest and best after all? I have not left it very far, and I certainly mean to go back to it." (194)

Likewise, in chapter 15 of Elizabeth Gaskell's North and South (1855), Mr. Thornton consciously and rather ponderously takes up a metaphor proposed by Margaret Hale, to whom he already feels himself attracted. (Their interchange is discussed in some detail by Gallagher 166-68). Similar examples abound. 
ously between the narrator and the characters themselves. And although it does not feature even a single wedding, its protagonist, the egoistic Sir Willoughby Patterne, finds himself (unusually for a Victorian novel) engaged to three different women over the course of the story. The central foursome of The Egoist - Willoughby, his second fiancée Clara Middleton, his devoted admirer Laetitia Dale, and his cousin Vernon Whitford - enter into almost every possible permutation of betrothal to one another, whether officially declared or merely urged, rumored, or tacitly understood. ${ }^{8}$ It therefore serves as an exemplary text for examining the significance of the trope.

In the first place, the trope's implicit equation of conversational and connubial compatibility serves as a reminder of the fundamentally discursive aspect of marriage. As Daub writes, the element that "distinguishes love [from] marriage, even in someone like Fichte who insists that they are functionally identical, is nothing other than the question of discourse. .. . From the 'I do' to the marriage manual, marriage depends on text, tradition, ritual, or simply common scripts of domestic life" (33). Both legally and spiritually, a marriage is a marriage because of the words that are shared between the partners. This discursive element has long been recognized: John Milton, whose pamphlets of the 1640s constitute the first extended articulation in English of the modern ideal of companionate marriage, consistently singled out dialogue between spouses, rather than sexual relations, as the indispensable element of conjugal love. Even the official legal term for adultery, "criminal conversation," reflects the same perception (Craig 199).

Yet although marriage has always been rooted in discourse, it is fair to say that nineteenth-century England witnessed what Michel Foucault would describe as "a veritable discursive explosion" on the subject (17). ${ }^{10}$ Public debate about the laws and rights of matrimony began to increase significantly in the wake of the French Revolution, when discus-

\footnotetext{
${ }^{8}$ The foursome recalls Aristotle's claim that metaphor usually involves four elements, since when a poet says, for instance, that evening is the old age of day, it really means that evening is to the day what old age is to life. See Aristotle 63 (1457b; ch. 21).

${ }^{9}$ See for instance The Doctrine and Discipline of Divorce (1643), where Milton declares that "a meet and happy conversation is the chiefest and the noblest end of marriage" (II: 246), a sentiment he repeats in various forms in the ensuing chapters.

${ }^{10}$ Foucault is here referring to sex, which he claims "was driven out of hiding and constrained to lead a discursive existence" over the course of the eighteenth and nineteenth centuries. The case of marriage is parallel though scarcely identical, since marriage was never in "hiding" but has always existed as a matter of public declaration and discussion.
} 
sion of the rights of man led naturally to considerations of the rights of women, including those of married women. ${ }^{11}$ But marriage truly became a leading subject of public discourse in England around the middle of the nineteenth century, when the movement for legal reform of the institution began to gain traction. "There had been endless debate in the early nineteenth century about marriage . . . but only one piece of legislation had dinted the legal rights of husbands" (Perkin 293). A barrage of public petitions to Parliament in 1856 , however, led at last to the $\mathrm{Di}$ vorce and Matrimonial Causes Act of 1857, which was followed by three further Matrimonial Causes Acts before the end of the century (1859, $1878,1884)$ as well as two versions of the Married Women's Property Act $(1870,1882) .{ }^{12}$ The debates concerning these reforms took place not only in Parliament but in journals, pamphlets, and books, and thus included women's voices as well as men's. A significant part of the debate, moreover, concerned the rights of a married woman to speak for and represent herself, rather than having her words, as well as her body and property, subsumed by her husband.

The legal concept at the heart of all the debate was coverture, according to which a woman, in the eyes of the law, ceased to exist as an independent person upon her marriage. ${ }^{13}$ This restriction applied to a wife's spoken and written language, as well as to all other things belonging to her. In Marriage; As It Was, As It Is, and As It Should Be (1879), the pioneering reformer Annie Besant pointed out the absurdities that result from the legal fiction that a husband's and wife's words are identical. She notes for instance the fact "that 'a husband cannot covenant or contract with his wife,' even for her own advantage" (8), since such a covenant would be the legal equivalent of a contract by the husband with himself - a tautology. Moreover, Besant observes, as a result of this equation of their voices, husbands and wives could not testify for or against each other in court, and a husband could actually be held responsible for slanders pronounced by his wife, even without his knowledge. In short, "A large amount of injustice arises from this absurd fiction that two are one" (9).

Besant was only one of many Victorians - John Stuart Mill was another - calling for the abolition of coverture. But as Wendy Jones has

${ }^{11}$ In A Vindication of the Rights of Woman (1792), for instance, Mary Wollstonecraft concentrates on women's education, but she begins at several points to address the question of marriage (e.g., 61-64, 231-34).

${ }^{12}$ See Shanley for useful individual chapters on the Acts of 1857, 1870, and 1882.

${ }^{13}$ For an informative overview of this topic, see Ablow 10-15. 
argued, social practice in this case moved in advance of legal reform. Marriages arranged entirely by parents had given way, over the previous centuries, to ones in which the final decision to marry rested with the participants (though this right was much more recent in the case of the woman). And such betrothals, Jones suggests, led to an increasing perception of marriage itself as a partnership: "Consensual married love implied what I call a 'contractual subjectivity' for women that was . . . ultimately incompatible with women's subjection. If men and women entered marriage voluntarily out of mutual regard, this implied that a woman should not be subordinate to her husband, or considered his inferior" (5). ${ }^{14}$ Contemporary fiction meanwhile both reflected and contributed to these shifting perceptions. The traditional courtship novel, in which marriage marks the vanishing-point for the protagonists, continued to flourish throughout the nineteenth century; but it was increasingly complemented by novels that followed the lovers through their courtship and wedding and well into their subsequent life - a form of narrative that required the protagonists to maintain their autonomy and difference after marriage. The notion of a total subsuming of one spouse by the other, as both a legal and social fiction, thus weakened steadily over the course of the Victorian period, to be replaced by something more dyadic. In broad terms, tautology gave way to metaphor, the notion of coverture to an ideal of colloquy. ${ }^{15}$

The pervasive and evolving Victorian discourse surrounding marriage (and its discourses) is reflected in The Egoist, published the same year as Besant's pamphlet. Meredith's characters consistently look to discursive markers as signs of nuptial eligibility. Not long after his engagement to Clara, Willoughby enjoys a particularly sprightly interchange with

${ }^{14}$ Jones traces these changes to the Enlightenment: "This new ethic had its origins in classic liberalism, in particular the writings of John Locke, whose account of the contractual origins of civil society epitomized an emergent 'structure of feeling.' . . . The very function of marriage as a partnership ... depends on a liberal notion of marriage as a contractual relationship" $(4,11)$.

${ }^{15}$ Such a broad claim necessarily glosses over the complexity and unevenness of this general development. The most comprehensive history of marriage in England up to, and through, the nineteenth century is given by Lawrence Stone; see especially 1977 and 1990. On the importance of the novel to this historical development, as both product and agent of a new form of female authority in the nineteenth century, see above all Nancy Armstrong (1987). Like Jones, Armstrong highlights the importance of the contract to Enlightenment thinking, seeing it as the basis of the domestic (often marriage-oriented) narrative central to nineteenth-century conceptions of the novel (28-58). 
his old admirer Laetitia and is immediately struck with misgivings: "He passed on regretfully. Clara Middleton did not study and know him like Laetitia Dale" (90). Clara herself feels the same way. Although she tries to "[imitate] Miss Dale's colloquial responsiveness," she inwardly hopes that Willoughby will recognize Laetitia's superior conversational ability (at least in dialogue with him) and so marry her instead: "he might . . . possibly see in Miss Dale, by present contrast, the mate he sought; by contrast with an unanswering creature like herself" (170). Clara feels she will not "answer" as a wife, in more ways than one.

But if dialogue is held in The Egoist as the necessary foundation of marriage, metaphor appears as its correlative. When Clara is first introduced to Patterne Hall as Willoughby's affianced bride, the whole neighborhood rushes to find an apt comparison for her. Vernon Whitford compares her "to the Mountain Echo," Lady Busshe to "the angels of Luini," and Lady Culmer to "crayon sketches of . . . the French aristocracy" (94-96). Another person "mentioned an antique statue of a figure breathing into a flute, ... but this comparison was repelled as grotesque" (96). At last the reigning wit of the neighborhood, Mrs. Mountstuart Jenkinson, delivers her own metaphor and pronounces Clara to be "a dainty rogue in porcelain" (95). Mrs. Mountstuart is renowned for hitting off resemblances exactly, but for once her figure fails to meet with success. Willoughby, who had earlier accepted her far more gnomic pronouncement about himself ("You see he has a leg" [65]) without question, quibbles with her metaphor for Clara because it does not seem to him to run on all four legs:

"Why rogue?" he insisted with Mrs. Mountstuart.

"I said - in porcelain," she replied.

"Rogue perplexes me."

"Porcelain explains it."

...

"Rogue and mistress of Patterne do not go together."

"Why not? She will be a novelty to our neighbourhood and an animation to the Hall."

"To be frank, rogue does not rightly match with me." (97)

The failed or at least contested metaphor strikes a foreboding note at the very outset of the central marriage plot. This may explain why Mrs. Mountstuart seems so wary of metaphor near the end of the novel, when she demands Clara's reasons for wishing to break off her engagement to Willoughby: 
"I found I could not give him the admiration he has, I daresay, a right to expect. I turned - it surprised me: it surprises me now. But so completely! So that to think of marrying him is..."

"Defer the simile," Mrs. Mountstuart interposed. "If you hit on a clever one, you will never get the better of it." (393)

As Randall Craig rightly explains in his analysis of this passage (18993), metaphors are here directly equated with promises: they are not something to be entered into lightly.

Hence the second and perhaps greater significance of the trope. When we witness characters in a novel sharing a metaphor, we see them engaged upon a serious business, since - unlike the other forms of banter they may enjoy - metaphor serves as a marital microcosm. The Ego$i s t$ is singularly devoid of married couples. All the older generation are widowed, and the novel ends with just one engagement and one hinted engagement, without even a traditional epilogue, like the one in Jane Eyre, sketching out the course of the protagonists' eventual marriage. Yet in the readiness with which characters take up or fail to take up each other's metaphors, the reader may see not only whether they are likely to marry but what would be the result if they did. Each of these interchanges thus offers the glimpse of a phantom plot - a miniature, counterfactual equivalent of Jane Eyre's epilogue.

From the opening of The Egoist, Willoughby casts himself as both matchmaker and metaphor-maker. At a ball that he hosts early in the novel, Willoughby sets up his cousin Vernon with Laetitia, while himself dancing with Constantia Durham, to whom he is about to become engaged; and he takes this occasion to make fun of his cousin (a clumsy dancer) in a series of metaphors:

Vernon was likened to Theseus in the maze, entirely dependent upon his Ariadne; to a fly released from a jam-pot; to a "salvage," or green, man caught in a web of nymphs and made to go the paces. Willoughby was inexhaustible in the happy similes he poured out to Miss Durham. . . Rumour went the round that he intended to give Laetitia to Vernon for good when he could decide to take Miss Durham to himself. (70-71)

Yet Willoughby's happy similes are all one-sided; Miss Durham does not respond to them. Nor will she answer as a wife: shortly after her engagement to Willoughby, she jilts him to elope with another man.

Willoughby's wedding plans for Vernon and Laetitia are equally vain. If this were not clear from the fact that they are so perfectly parallel - both are generous, literary, self-sacrificing characters in straitened 
circumstances - it becomes quite plain in one of their few extended conversations together. Their dialogue begins with a shower of mutual compliments (what Meredith calls a "pelting of . . interlaudation" [367]) but comes to a halt when Vernon refuses her praise by means of a metaphor, and Laetitia does the same:

"Oh! - pardon me, But you inflict the sensations of a boy, with a dose of honesty in him, called up to receive a prize he has won by the dexterous use of a crib."

"And how do you suppose she feels, who has a crown of Queen o' the May forced on her head when she is verging on November?"

He rejected her analogy, and she his. (367)

Laetitia does not pursue Vernon's metaphor but instead introduces a similar one of her own, which remains equal but separate. The failure to share is reminiscent of an interchange between Jane Eyre and St. John Rivers:

"But I apprised you that I was a hard man," said he; "difficult to persuade."

"And I am a hard woman, - impossible to put off."

"And then," he pursued, "I am cold: no fervour infects me."

"Whereas I am hot, and fire dissolves ice...."

"Well, then," he said, "I yield; if not to your earnestness, to your perseverance: as stone is worn by continual dropping." (Brontë 428)

The dialogue is lively and companionable enough. The pair, like Vernon and Laetitia, are well matched, and indeed the result of their conversation is that St. John reveals himself to be none other than Jane's first cousin. But Jane is clearly right to reject St. John's repeated proposals of marriage. He refuses to enter into her metaphor of fire and ice, preferring to impose his own image of water and stone, which both places him at greater advantage and also subtly reduces Jane to his element (Rivers). Jane repeatedly claims to be able to envision exactly how St. John would behave as a husband; in this exchange the reader is given a similar vision.

Clara Middleton, by contrast, makes an active effort to enter into Willoughby's metaphors but is thwarted:

"My feelings, dearest, are too strong for transcription. I feel, pen in hand, like the mythological Titan at war with Jove, strong enough to hurl mountains, and finding nothing but pebbles. The simile is a good one. You must not judge me by my letters."

"I do not; I like them," said Clara. 
She blushed, eyed him hurriedly, and seeing him complacent, resumed: "I prefer the pebble to the mountain; but if you read poetry you would not think human speech incapable of ..."

"My love, I detest artifice." (Meredith 118)

Even before Willoughby cuts off her response mid-sentence, the dialogue has already gone awry. Both speakers are too self-conscious with regard to his simile, which Clara can only at last commend, not continue. By contrast Willoughby seems utterly unconscious of Clara's metaphors. When he proposes to let her wear his family pearls before the wedding, she proffers a striking simile in return; but he can see only his own offering:

"As my betrothed, will you wear them, to please me?"

"I would rather not. I cannot wear borrowed jewels. These I cannot wear. Forgive me, I cannot. And, Willoughby," she said, . . . "does one not look like a victim decked for the sacrifice - the garlanded heifer you see on Greek vases, in that array of jewellery?"

"My dear Clara!" exclaimed the astonished lover, "how can you term them borrowed, when they are the Patterne jewels, our family heirloom pearls[?]" (150)

Clara might have said, like him, "The simile is a good one"; but her metaphor of the heifer falls like pearls before swine.

Willoughby is much more attentive, however, to Clara's father, whose help he requires in getting Clara to go through with the wedding. The wooing of Dr. Middleton provides not only one of the comic highlights of the novel but one of the great seduction scenes in Victorian literature. Willoughby's secret weapon is a cellar full of ninety-year-old port. Dr. Middleton is a scholar, and in Meredith's apt phrase, "Of all our venerable British . . . the classic scholar is he whose blood is most nuptial to the webbed bottle" (235). No sooner is port mentioned, therefore, than Dr. Middleton launches into a series of rhapsodic metaphors, to which his would-be son-in-law does his best to respond:

"I cherish the fancy that Port speaks the sentences of wisdom; Burgundy sings the inspired Ode. Or put it, that Port is the Homeric hexameter, Burgundy the Pindaric dithyramb. What do you say?"

"The comparison is excellent, sir."

"The distinction, you would remark. Pindar astounds. But his elder brings us the more sustaining cup. One is a fountain of prodigious ascent. One is the unsounded purple sea of marching billows."

"A very fine distinction."

"I conceive you to be now commending the similes." (233) 
Despite Willoughby's self-conscious efforts, "He was about as accordantly coupled with Dr. Middleton in discourse as a drum duetting with a bass-viol; and when he struck in he received correction from the pedagogue-instrument" (234).

Yet Willoughby patiently continues to attend to Dr. Middleton's metaphors, and with the help of the wine itself, his efforts are finally rewarded:

"You will not object to drink it, sir, to the health of your grandchildren. And may you live to toast them in it on their marriage-day!"

"You colour the idea of a prolonged existence in seductive hues. Ha! It is a wine for Tithonus. This wine would speed him to the rosy Morning - aha!"

"I will undertake to sit you through it up to morning," said Sir Willoughby, innocent of the Bacchic nuptiality of the allusion. (236)

Willoughby's attempt to engage with the doctor's metaphor is just as awkward as his earlier efforts, but this time Dr. Middleton takes the will for the deed and refrains from correcting him. Indeed, no correction is necessary: Willoughby may not have intended to cast himself as the doctor's spouse, but the "nuptiality of the allusion" is entirely appropriate to the situation. For all their differences, the two men have found their one great point of likeness, and from this moment on Dr. Middleton considers himself Willoughby's ally as much as if he had pledged his troth. "A fresh decanter was placed before the doctor. He said: 'I have but a girl to give!' He was melted" (237).

Dr. Middleton's association of wedlock with wine, implied in this exchange, is well established. The opening of the biblical Song of Songs declares, "Let him kiss me with the kisses of his mouth: for thy love is better than wine" (1:2). The Song of Songs provides one of the chief sources of the marriage ceremony's assertion that earthly marriage serves as a mere metaphor for divine love, since a venerable exegetical tradition allegorizes the Song's eroticism in terms of the mutual love of Christ and his spouse, the Church. (The Geneva gloss to the opening verse, for instance, explains, "This is spoken in the person of the Church, or of the faithful soul inflamed with the desire of Christ, whom she loves.") Dr. Middleton may be thinking in part metaphorically, therefore, when he trades his daughter's love for wine, since in addition to being a classical scholar he is also a retired clergyman. His clerical vocation, in fact, provides the material for one of the metaphors that he and Willoughby share when they labor together to try to bring Clara to the altar. Willoughby enters a room in which Dr. Middleton has been lecturing his daughter on the necessity of keeping her promise to marry. 
"You are disengaged, sir?"

"The sermon is upon the paragraph which is toned to awaken the clerk," replied the Rev. Doctor.

Clara was weeping.

Sir Willoughby drew near her solicitously. . . .

"The clerk, sir, has pronounced Amen," observed Willoughby.

"And no man is happier to hear an ejaculation that he has laboured for with so much sweat of his brow than the parson, I can assure you," Dr. Middleton mildly groaned. (439-40)

This is Willoughby's most successfully shared metaphor. The wine has worked its nuptial magic.

Happily for Clara, however, circumstances change, and she is released at last from her engagement to Willoughby. She ends the novel free from any formal promise, but with a plan to meet Vernon Whitford in the Alps a few months later. There, we assume, they will be betrothed: Clara has declared that she will marry no one else; Vernon has made his intentions clear and has already received her father's blessing. But in place of a formal proposal, we witness instead this final conversation between the two before Clara sets off on her travels:

"Of course," she flew from him, "big mountains must be satisfied with my admiration at their feet."

"That will do for a beginning."

"They speak encouragingly."

"One of them." Vernon's breast heaved a sigh.

"To be at your feet makes a mountain of you?" said she.

"With the heart of a mouse if that satisfies me!"

"You tower too high; you are inaccessible."

"I give you a second warning. You may be seized and lifted."

"Some one would stoop, then."

"To plant you like the flag on the conquered peak!" (525)

This densely riddling passage reaches Jamesian depths of implication. Tellingly, the metaphor Clara introduces concerns mountains - the same image she had earlier failed to share with Willoughby. Since she and Vernon have just been discussing the Alps, however, this is also a non-committal opening, as it leaves him the option of taking her statement literally should he so choose. But his coyly encouraging response emboldens her to make clear that she is indeed comparing him to a mountain. Although the modest Vernon would usually reject any such complimentary language - as he did in his conversation with Laetitia Dale - here he merely qualifies it ("with the heart of a mouse!") to 
satisfy his conscience while still faithfully pursuing Clara's metaphor. Consciously or not, Clara is putting Vernon to the test in requiring him to take up what is, to him, such an antipathetic image, and Vernon succeeds admirably. The immediate result of their conversation is a sense of mutual assurance: "their hands might join. The two hands thought so, or did not think, behaved like innocents" (525).

Clara and Vernon's use of shared metaphor to gauge their connubial compatibility reflects both a particular historical moment and a broader psychological phenomenon. In a recent book, the aesthetic philosopher Ted Cohen posits a fundamental connection between what he calls "the talent for metaphor" and our ability to identify with other human beings. Cohen writes that "the creation, expression, and comprehension of metaphors must involve speaking and thinking of one thing as another. I am persuaded that understanding one another involves thinking of oneself as another, and thus the talent for doing this must be related to the talent for [metaphor]; and it may be the same talent, differently deployed" (9). (This line of thought has strong Victorian antecedents: the critic E. S. Dallas, for instance, similarly sees metaphorical thinking as the basis for all fellow-feeling. ${ }^{16}$ ) Following Cohen's logic, when we witness Clara and Vernon's shared ability to imagine a human being as a mountain or Jane and Rochester's to imagine someone as a bee, or a tree - we are

${ }^{16}$ Dallas asserts the connection between metaphorical thinking and sympathy with others in his 1866 magnum opus, The Gay Science: "[T]hroughout all art and life the formula of sympathy is this: I am you, or like you; I am, or am like, or at least I wish to be, or to be like, something which is not myself" (276). Dallas cites as evidence the immediate sympathy that springs up between Romeo and Juliet, beginning when Romeo compares himself to a pilgrim worshipping at her shrine - to which Juliet responds in kind, continuing his metaphor while challenging his conclusions, in precisely the way we have seen. Dallas' example is Elizabethan, since (as noted above) neither the trope nor the connection it suggests is peculiar to the Victorian period; but his observation of it, and his insistence on the interpersonal significance of metaphor, are typical of his time.

Adela Pinch, in an article about what Coventry Patmore calls "love thinking" - that is, shared imagination between lovers (though the article is not directly concerned with metaphor) - suggests that Victorian writers were generally far less optimistic about these forms of sympathetic thought. Regarding Meredith's sequence of poems Modern Love (1862), she writes, "Modern Love is fundamentally skeptical about the value that psychological insight into or understanding of another person may have in an intimate relationship, and even more, it is skeptical of the value of thinking about the one you love, at all" (387). Although it is true that thought alone is insufficient to solve the marital difficulties of the protagonists of Modern Love, I would dispute Pinch's claim that Meredith did not consider love thinking to be essential to marital success. 
also witnessing their ability, and their willingness, to identify with each other. At the same time, as their dialogues reveal, they preserve the sense of inherent difference that is essential to any successful metaphor and that likewise figured with increasing prominence in nineteenth-century conceptions of marriage. Hence the significance of the trope in these novels: when lovers in conversation with one another share in the creation of a metaphor, they can be seen to participate in a fundamental form of marital collaboration.

\section{Works Cited}

Ablow, Rachel. 2007. The Marriage of Minds: Reading Sympathy in the Victorian Marriage Plot. Stanford: Stanford University Press.

Aristotle. 1980 [1909]. Poetics. Trans Ingram Bywater. New York: Garland.

Armstrong, Nancy. 1987. Desire and Domestic Fiction: A Political History of the Novel. New York: Oxford University Press.

Besant, Annie. 1879. Marriage; As It Was, As It Is, and As It Should Be: With a Sketch of the Life of Mrs. Besant, Ed. Asa K. Butts. New York: Butts.

The Book of Common Prayer. 1815. Oxford: Clarendon.

Boone, Joseph Allen. 1987. Tradition Counter Tradition: Love and the Form of Fiction. Chicago: University of Chicago Press.

Brontë, Charlotte. 1996 [1847]. Jane Eyre. Ed. Michael Mason. London: Penguin.

Cohen, Ted. 2008. Thinking of Others: On the Talent for Metaphor. Princeton: Princeton University Press.

Coleridge, Samuel Taylor. 1976. On the Constitution of Church and State. Ed. John Colman. Princeton: Princeton University Press.

Craig, Randall. 2000. Promising Language: Betrothal in Victorian Law and Fiction. Albany: SUNY Press.

Dallas, E. S. 1866. The Gay Science. London: Chapman and Hall.

Daub, Adrian. 2012. Uncivil Unions: The Metaphysics of Marriage in German Idealism and Romanticism. Chicago: University of Chicago Press.

Foucault, Michel. The History of Sexuality: An Introduction. Trans. Robert Hurley. New York: Vintage, 1990.

Gallagher, Catherine. 1985. The Industrial Reformation of English Fiction: Social Discourse and Narrative Form 1832-1867. Chicago: University of Chicago Press.

Gray, Erik. 2006. "Faithful Likenesses: Lists of Similes in Milton, Shelley, and Rossetti." Texas Studies in Literature and Language 48: 291-311.

Jones, Wendy S. 2005. Consensual Fictions: Women, Liberalism, and the English Novel. Toronto: University of Toronto Press. 
Kaye, Richard. 2002. The Flirt's Tragedy: Desire without End in Victorian and Edwardian Fiction. Charlottesville: University Press of Virginia.

Kintner, Elvan, ed. 1969. The Letters of Robert Browning and Elizabeth Barrett Browning, 1845-1846. Cambridge, MA: Harvard University Press.

Kristeva, Julia. 1987. Tales of Love. Trans. Leon S. Roudiez. New York: Columbia University Press.

Meredith, George. 2010 [1879]. The Egoist. Ed. Richard C. Stevenson. Peterborough: Broadview.

Milton, John. 1953-1982. Complete Prose Works of John Milton. 8 vols. Ed. Don M. Wolfe et al. New Haven: Yale University Press.

Perkin, Joan. 1989. Women and Marriage in Nineteenth-Century England. London: Routledge.

Pinch, Adela. 2008. "Love Thinking.” Victorian Studies 50/3: 379-97.

Punter, David. 2007. Metaphor. London: Routledge.

Rose, Phyllis. 1983. Parallel Lives: Five Victorian Marriages. New York: Knopf.

Shanley, Mary Lyndon. 1989. Feminism, Marriage, and the Law in Victorian England, 1850-1895. Princeton: Princeton University Press.

Stone, Lawrence. 1977. The Family, Sex and Marriage in England, 15001800. New York: Harper and Row.

- 1990. Road to Divorce: England 1530-1987. Oxford: Oxford University Press.

Tennyson, Hallam, Lord. 1897. Alfred Lord Tennyson: A Memoir. London: Macmillan.

Trollope, Anthony. 1989 [1861]. Framley Parsonage. Ed. P. D. Edwards. New York: Oxford University Press.

Wolfson, Susan. 1997. Formal Charges: The Shaping of Poetry in British Romanticism. Stanford: Stanford University Press.

Wollstonecraft, Mary. 1974 [1792]. A Vindication of the Rights of Woman: With Strictures on Political and Moral Subjects. New York: Garland.

Wordsworth, William. 1974. The Prose Works of William Wordsworth. Ed. W. J. B. Owen and Jane Worthington Smyser. 3 vols. Oxford: Clarendon. 